\title{
Using Social Media as Tools of Health Protocol Campaign in the Era of the Covid-19 Pandemic in Indonesia
}

\author{
Dimas Subekti \\ dsubekti05@gmail.com \\ Universitas Muhammadiyah Yogyakarta \\ Suranto \\ suranto@umy.ac.id \\ Universitas Muhammadiyah Yogyakarta
}

\begin{abstract}
The entry of Covid-19 in Indonesia prompted the Indonesian government to make policies to tackle the virus's spread. The approach adopted by the Indonesian government is large-scale social restrictions (PSBB). The problem is that there are still violations of health protocols that have created a new Covid-19 cluster amid society. Therefore, this study aims to find out more about the use of social media for health protocol campaigns in the era of the Covid-19 pandemic in Indonesia. This study uses Q-DAS (Qualitative Data Analysis Software) with NVIVO 12 plus for data analyses. This study uses three different analyses, chart, cluster, and word cloud analyses. This study uses trending hashtags on Twitter social media relevant to the health protocol campaign in the era of the Covid-19 pandemic. The results of this study are; first, twitter social media is one of the places to campaign for health protocols in the era of the Covid-19 pandemic. Second, the "physical distancing" health protocol campaign is dominant in \#SocialDistancing, "using a mask" is prevalent in \#jagajarak, and "handwashing" is often used in \#lawancovid19 and \#jagajarak. Third, several hashtags used in social media Twitter about health protocols are interconnected, but the most powerful are \#pakaimasker with \#jagajarak. Fourth, the most popular word, which is often discussed concerning health protocols on Twitter, is \#SocialDistancing.
\end{abstract}

Keywords: Social Media; Campaign; Health Protocol; Pandemic; Covid-19

\section{INTRODUCTION}

Corona Virus Deseas 2019 or commonly known as Covid-19, is a virus that causes disease in humans. The spread of this virus is fast enough that it has spread throughout the world, including Indonesia. The first time the Indonesian government announced two positive patients for Covid-19 was on March 2, 2020. At first, through the Ministry of Health, the Indonesian government was optimistic that Covid-19 would not enter Indonesia and stated that the virus was not dangerous. The minister of health Terawan conveyed this, "The important thing is to take action to live a healthy life. We all do it, as usual, what is different, nothing. Diphtheria is so great that we have nothing to fear. Moreover, this is the corona,".Furthermore, he also said, "Even though flu, coughs, colds usually happen to us, the death rate is higher than that of the corona. But why is this so exciting?" (Garjito, 2020). 
But the opposite is happening; data as of November 30, 2020, 538,883 confirmed patients positive for Covid-19 in Indonesia, 16,945 deaths (covid19.go.id/).

The entry of Covid-19 in Indonesia prompted the Indonesian government to make policies to tackle the virus's spread. The approach adopted by the Indonesian government is large-scale social restrictions (PSBB). The large-scale social restrictions (PSBB) policy was first implemented on April 10, 2020, in Jakarta, followed by several other areas in Indonesia(Ristyawati, 2020). Several regulations related to the implementation of large-scale social restriction policies (PSBB) are Government Regulation Number 21 of 2020 concerning Large-Scale Social Restrictions in the Context of Accelerating the Handling of Corona Virus Disease 2019 (Covid-19), Regulation of the Minister of Health Number 9 of 2020 concerning Guidelines for Large-Scale Social Restrictions in the Context of Accelerating Handling of Corona Virus Disease 2019 (Covid-19), as well as Government Regulation instead of Law Number 1 of 2020 concerning State Financial Policy and Financial System Stability for Handling the Corona Pandemic Virus disease 2019 and in the context of facing threats that endanger the national economy and financial system stability.

The implementation of a large-scale social restrictions policy by the Indonesian government to protect the public. But on the other hand, this policy's performance has caused economic difficulties for several people, such as transportation, tourism, hotels, restaurants, day traders, and others(Sufiarina \& Wahyuni, 2020). Therefore, several regions in Indonesia adopted transitional large-scale social restrictions (PSBB). The transitional PSBB is a transitional period from a period of limitation to the return of socio-economic activities that benefit the wider community. During the transition period, several socio-economic activities began to be opened gradually with the limits and health protocols of Covid-19(Untari, 2020). The Covid-19 health protocol, according to the health ministry and the task force to accelerate the handling of Covid-19, is washing hands, using masks, and maintaining distance.

The problem is that there are still violations of health protocols that have created a new Covid-19 cluster amid society. Such as the violation of health protocols when registering prospective pairs of candidates for simultaneous regional head elections in 2020. According to the Special Staff of the Minister of Home Affairs for Politics and Media, Kastorius Sinaga, 260 candidate pairs violate health protocols at registration(Nugraheny, 2020a). Due to the violation of the health protocol, based on the chameleon health examination letter received by the General Election Commission (KPU), 46 prospective pairs of candidates for simultaneous regional head elections in 2020 were exposed to Covid-19(Nugraheny, 2020b). Then there were health protocol violations in succession. First, a crowd of people picked up thousands of Habib Rizieq Shihab's supporters at Soekarno-Hatta airport. Second, there was a welcoming crowd of sympathizers with Habib Rizieq Shihab in Petamburan, Central Jakarta. The three events of the Prophet Muhammad SAW's birthday were attended by Habib Rizieq Shihab and thousands of masses without implementing the Covid-19 health protocol. And most recently, on Saturday, November 14, 2020, Habib Rizieq Shibab held a reception for his son's wedding in Petamburan. Ten thousand people attended the wedding(Fitang Budhi Adhitia, 2020). As a result, many of the crowds were confirmed positive for Covid-19, and the task force to accelerate the handling of Covid-19 was tracing the people involved in the group. Then other health protocol violations that occurred in various regions in Indonesia caused the new Covid-19 cluster.

Several previous studies are relevant to this research. Research about the involvement of social media influence and memes in increasing the reach of health campaigns. Campaigns that used social media influencers as message sources generated more campaign-branded and sharable content (e.g., campaign hashtags) and a higher volume of tweets per day and reach 
per day (Kostygina et al., 2020). Holistic social media campaign model for predicting health behaviors in the social media context. Social media-related perceptions indirectly impacted behavioral intention through communicative behaviors(Yoo, Kim, \& Lee, 2018).

The impact of an effective social media campaign in the UK health informatics research community. The findings suggest that the social media campaign encouraged individuals to show personal support for sharing health data by encouraging community building(Hassan, Nenadic, \& Tully, 2021). Harnessing Social Media for Health Promotion and Behavior Change. Rapid and inventive advancements in participatory Internet communications, dubbed "social media," provide prospects for changing health behavior. Although social media has a lot of potential as a tool for health promotion and education, they, like traditional health promotion media, need to be used carefully and may not always produce the desired results(Korda \& Itani, 2013). The use of social media in the promotion of health. Organizations and practitioners in health promotion must match their program requirements with realistic expectations of what social media can bring. For example, while precise applications can enhance the change process, social media should not be considered a panacea to the difficulties of behavior change and improved health outcomes(Neiger et al., 2012). Danish social media campaign to address HPV vaccination hesitancy. A comprehensive social media strategy using 'heart-brain communication' proved helpful in promoting HPV vaccination(Pedersen, Loft, Jacobsen, Søborg, \& Bigaard, 2020).

Youth health promotion activities, particularly for the highly stigmatized subject of mental health, may benefit from campaign communication tactics. It would be wise for youth-focused mental health initiatives to continue to use social media - preferably in several forms - to improve awareness of mental health symptoms and allow access to treatment when necessary(Goodman, Wennerstrom, \& Springgate, 2011). a social media effort in one Midwestern county aimed to reduce mental health stigma and increase help-seeking among 6th to 12th-grade children. Over a school year, the campaign used movie theater advertising, social media, web-based advertising, and school-based media/events(Thompson et al., 2020).

Based on the explanation above, this study aims to find out more about using social media for health protocol campaigns in Indonesia's era of the Covid-19 pandemic. This research focuses on the Covid-19 health protocol campaign in Indonesia using social media, especially Twitter. This study tries to answer the function and relationship between social media and the Covid-19 health protocol campaign and what kind of narrative is spreading on social media regarding the Covid-19 health protocol.

\section{SOCIAL MEDIA EFFECT}

According to Valentini and Kruckeberg (2012), social media's definition focuses on the behavior and interactions created between users. Individuals use social media, and social media does not exist without the user(Allagui \& Breslow, 2016). Social media is a forum to collect information or news from family, friends, or traditional organizations for news media(Boulianne, 2015). The role of social media in enabling communication to social networks that can be mobilized. The web can be split into three streams: a focus on the size of the network; a focus on social ties to groups, organizations, and activists; and a focus on diffusion through peer groups(Valenzuela, 2013). Social media has far-reaching effects as the use of social media in dakwah by One Day One Juz (ODOJ), which endeavors to encourage Muslims to revive the spirit of reading the Qur'an through the mobile application WhatsApp(Nisa, 2018). While encouraging freedom of expression, social media also emboldens freedom to hate, where individuals exercise their right to voice their opinions while actively silencing others(Lim, 2017). 
In all spheres of life, social media is emerging as an influencing force. Social media and ICTs facilitate communication between different stakeholders, enabling feedback and promoting citizen participation. By promoting transparency, government responsiveness, and citizen participation, the innovative use of technology contributes to democracy(R. Kumar, Kumar, \& Ilavarasan, 2017). In social media campaigns, user engagement has become an essential component that strategic communication specialists need to pay attention (Paek, Hove, Jung, \& Cole, 2013). Social media's use coincides with the emergence of a new campaign strategy at the end of the last century called the professional campaign(Vergeer \& Hermans, 2013). Seven approaches to ensure a successful social media campaign, first monitor the conversations, identify influential individuals who can spread messages, and identify the factors shared by influential individuals. Fourth, locate those potential influencers who have interests relevant to the campaign. Fifth, recruit those influencers with parts pertinent to the campaign to talk about the company's product or service. Sixth, incentivize those influencers to spread positive WOM about the product or service. Seventh, reap the rewards from increasingly effective social media campaigns(V. Kumar \& Mirchandani, 2012).

\section{HEALTH PROTOCOL}

The World Health Organization recommends several things to deal with the Covid-19 outbreak in the form of essential protection, such as washing hands regularly with alcohol or soap and running water, keeping a distance from someone who has symptoms of coughing or sneezing with a length of one meter, practicing cough etiquette or sneeze, and seek treatment when you have a complaint that fits the suspect category(Adi Antoni, Arinil Hidayah, 2020). World Health Organization (WHO) calls on various countries to collaborate to implement unique health protocols to prevent Covid-19. The implemented health protocol will prevent the transmission of Covid-19(Sari, Setyawan, Supriyadi, \& Purwitaningtyas, 2020).

Research on the Covid-19 health protocol is still very minimal, especially in Indonesia. Covid-19 is a new virus and a new pandemic that is spreading throughout the world. Several studies have discussed the Covid-19 health protocol. Research entitled education on health protocols and online marketing strategies through community partnership programs in the era of the Covid-19 pandemic. All of which is the Community Partnership Program (PKM), which is a form of community service that goes well, including education on health protocols for new chronic adaptations in the Covid-19 pandemic era, socialization on processing management and product marketing strategies and product packaging, and online marketing training through social media (target audience knowledge increased by $80 \%$ )(Irawan, Triana, Suwarni, \& ..., 2020).

Other studies have explained that everyone must maintain physical health during the Covid 19 pandemic by implementing entry and exit protocols. The public can find out, recognize, and deal with physical health problems, including signs and symptoms of Covid19 (Tuti Meihartati, Aries Abiyoga, Dodi Saputra, 2020). Research also discusses training in implementing health protocols, making natural hand sanitizers, and family food security during the Covid-19 pandemic(Siregar, 2020). Another study that discusses health protocols explains that health education based on the WhatsApp application can help residents of the Griya Nato Ujung Gurap housing community prevent Covid-19 transmission on Eid alFitr(Adi Antoni, Arinil Hidayah, 2020). The findings of other studies suggest that the knowledge of new nursing students about the covid 19 protocol results in that most of them have good experience as many as 49 (79\%)(Sari et al., 2020). 


\section{METHOD}

This study uses Q-DAS (Qualitative Data Analysis Software) with Nvivo 12 plus for data analysis. This study uses three different analyzes, chart analysis, cluster analysis, and word cloud analysis. All data in this study are social media data. This study uses trending hashtags on Twitter social media relevant to the health protocol campaign in the era of the Covid-19 pandemic. The study used the 12 hashtags listed in table 1 below.

TABLE 1. Hashtags and Description

\begin{tabular}{|c|c|}
\hline Hashtags & Description \\
\hline \#cegahcovid19 & $\begin{array}{c}\text { This hashtag is used to invite to ward off } \\
\text { Covid-19. }\end{array}$ \\
\hline \#CuciTanganPakaiSabun & $\begin{array}{l}\text { Wash your hands more effectively with } \\
\text { soap to prevent Covid-19. }\end{array}$ \\
\hline \#ingatpesanibu & $\begin{array}{l}\text { Government campaigns for the public to } \\
\text { comply with health protocols. }\end{array}$ \\
\hline \#jagajarak & $\begin{array}{c}\text { This hashtag is used to promote everyone, } \\
\text { not to the crowd. }\end{array}$ \\
\hline \#janganlupa3M & $\begin{array}{l}\text { This hashtag is used to remind the } \\
\text { implementation of health protocols. }\end{array}$ \\
\hline \#lawancovid19 & $\begin{array}{l}\text { This hashtag is used as an invitation to face } \\
\text { Covid- } 19 \text {. }\end{array}$ \\
\hline \#pakaimasker & Use a mask in all activities. \\
\hline \#patuhiprotokolkesehatan & $\begin{array}{l}\text { Invites everyone to adhere to health } \\
\text { protocols. }\end{array}$ \\
\hline \#PelanggaranProtokolKesehatan & $\begin{array}{c}\text { These hashtags show that health protocol } \\
\text { violations still occur in society. }\end{array}$ \\
\hline \#pilkadaamanpatuhiprokes & $\begin{array}{l}\text { This hashtag is used for the holding of the } \\
2020 \text { regional elections to implement health } \\
\text { protocols. }\end{array}$ \\
\hline \#protokolkesehatan & $\begin{array}{l}\text { The method used to reduce the spread of } \\
\text { Covid-19. }\end{array}$ \\
\hline \#SocialDistancing & $\begin{array}{c}\text { Limiting social contact to prevent the spread } \\
\text { of Covid-19. }\end{array}$ \\
\hline
\end{tabular}

$\mathrm{N}$-capture application is used to download the hashtags content. The Nvivo 12 Plus chart analysis uses three words: physical distancing, using a mask, and washing hands. Because these three are basic health protocols that have been campaigned and implemented to prevent the transmission of Covid-19. Cluster analysis is used to understand the relationship between these hashtags. While the world cloud is used to find out topics discussed related to health protocol campaigns.

\section{DISCUSSION}

\section{THE FUNCTION AND RELEVANCE OF THE HEALTH PROTOCOL CAMPAIGN ON SOCIAL MEDIA}

The use of hashtags on Twitter social media can help determine the health protocol campaign in the era of the Covid-19 pandemic. Twelve hashtags were used as the primary source in this research. The hashtags are \#cegahcovid19, \#CuciTanganPakaiSabun, \#ingatpesanibu, \#jagajarak, \#Janganlupa3M, \#lawancovid19, \#pakaimasker, \#patuhiprotokolkesehatan, \#pelanggaranprotokesolkesehatan, \#pilkadaamanpatuhiprokes, \#protokolkesehatan, \#SocialDistancing. The coding process uses three nodes, namely 
"physical distancing," "using a mask," and "washing hands." The chart analysis in Figure 1 helps to understand the percentage of tweets in hashtags.

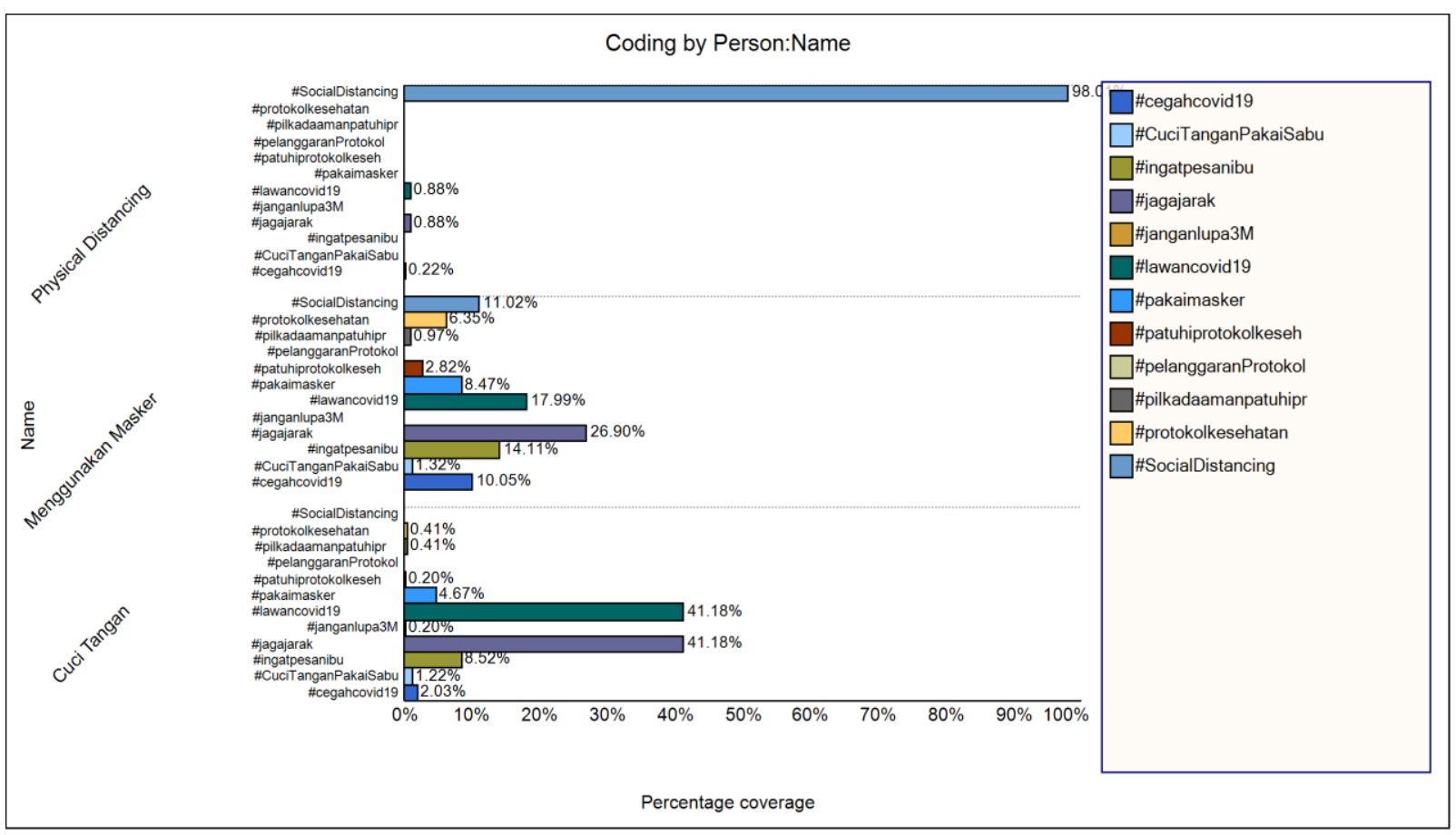

FIGURE 1. The chart analysis of the hashtags

The chart analysis results above show that physical distancing gets the highest value on \#SocialDistancing, 98.0\%. Meanwhile, the other hashtags are less than 1\%. This indicates that the narrative about physical distancing is often discussed in \#SocialDistancing and is less discussed in other hashtags. The "wearing a mask" node received the highest score at \#jagajarak with 26.90, followed by \#lawancovid19 with $17.99 \%$. This shows that the "wearing a mask" narrative is often discussed and used in \# lawancovid19. And the one who got the lowest score was \#CuciTanganPakaiSabun, with a value of $1.32 \%$. Furthermore, in the node "wash hands," the highest scores were \#lawancovid19 and \#jagajarak, which were both $41.18 \%$. Narratives on "washing hands" were frequently used and discussed at \#lawancovid19 and \#jagajarak.

The health protocol campaign on social media Twitter has links to 12 of these hashtags. Cluster analysis in Figure 2 shows each hashtag's relationship. This is to help understand the connectivity between one hashtag to another. 


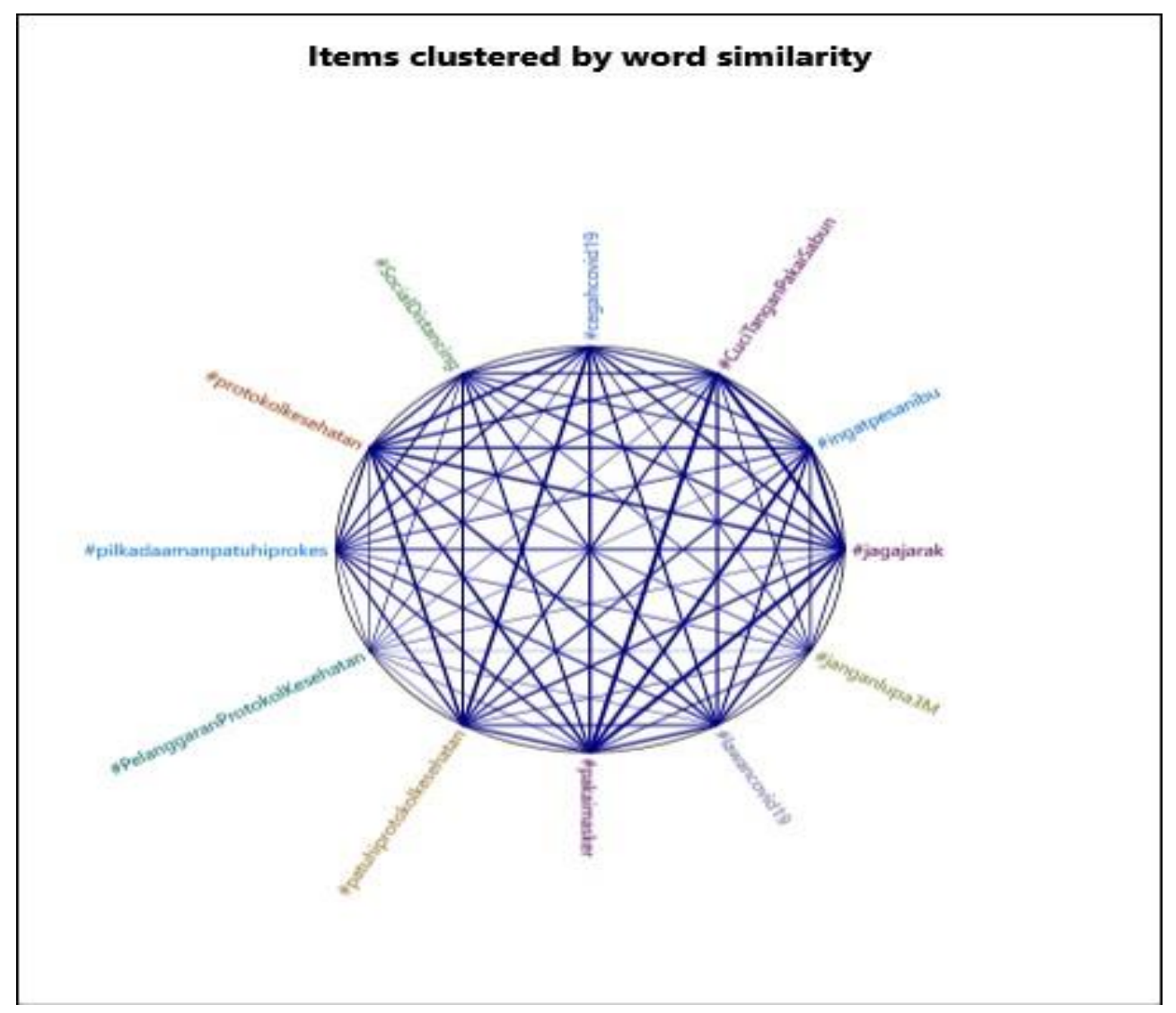

FIGURE 2. Cluster analysis of the hashtags.

Based on the results of the cluster analysis above, each hashtag has a relationship with one another. \#pakaimasker with \#jagajarak has the highest relationship, followed by \#pakaimasker with \#CuciTanganPakaiSabun. This shows that the hashtag is heavily discussed and serves as a health protocol campaign on Twitter's social media. Meanwhile, \#PelanggaranProtokolKeSehatan with \#jangalupa3M had the lowest relationship. The following table 2 shows a cluster analysis of the number of relationship coefficients of each hashtag campaigning for health protocols on Twitter.

TABLE 2. The coefficient number of the hashtags relationship

\begin{tabular}{ccc}
\hline Hashtags A & Hashtags B & $\begin{array}{c}\text { Pearson correlation } \\
\text { coefficient }\end{array}$ \\
\hline \#pakaimasker & \#jagajarak & 0.937904 \\
\#pakaimasker & \#CuciTanganPakaiSabun & 0.913109 \\
\#jagajarak & \#CuciTanganPakaiSabun & 0.875072 \\
\#ingatpesanibu & \#CuciTanganPakaiSabun & 0.855227 \\
\#pakaimasker & \#ingatpesanibu & 0.83485 \\
\#jagajarak & \#ingatpesanibu & 0.804833 \\
\#patuhiprotokolkesehatan & \#cegahcovid19 & 0.760748 \\
\#protokolkesehatan & \#cegahcovid19 & 0.743749 \\
\#protokolkesehatan & \#patuhiprotokolkesehatan & 0.682082 \\
\#protokolkesehatan & \#pakaimasker & 0.680744 \\
\#pilkadaamanpatuhiprokes & \#patuhiprotokolkesehatan & 0.542758 \\
\#SocialDistancing & \#protokolkesehatan & 0.542025 \\
\#PelanggaranProtokolKesehatan & \#patuhiprotokolkesehatan & 0.240372 \\
\hline
\end{tabular}




\begin{tabular}{ccc}
\hline \#pilkadaamanpatuhiprokes & \#PelanggaranProtokolKesehatan & 0.238848 \\
\#PelanggaranProtokolKesehatan & \#lawancovid19 & 0.23358 \\
\#PelanggaranProtokolKesehatan & \#CuciTanganPakaiSabun & 0.220939 \\
\#PelanggaranProtokolKesehatan & \#ingatpesanibu & 0.204973 \\
\#PelanggaranProtokolKesehatan & \#janganlupa3M & 0.145296 \\
\hline
\end{tabular}

The data above shows that \#pakaimasker and \#jagajarak have the highest relationship, which is 0.937904. The second is \#pakaimasker with \#CuciTanganPakaiSabun, which is 0913109. The third is \#jagajarak with \#CuciTanganPakaiSabun, namely with the number 0.875072. The lowest three hashtag relationships are \#PelanggaranProtokolKesehatan with \#lawancovid19 with the value of 0.220939, \#PelanggaranProtokolKesehatan with \#Ingatpesanibu worth 0.204973, and \#PelanggaranProtokolKesehatan with \#janganlupa3M worth 0.145296 .

\section{THE NARRATIVE ON TWITTER SOCIAL MEDIA ABOUT THE HEALTH PROTOCOL CAMPAIGN}

The narrative discussed in connection with the health protocol campaign on Twitter social media can be seen through world cloud analysis. World cloud analysis shows the top 100 words on Twitter's social media originating from hashtags, as shown in figure 3.

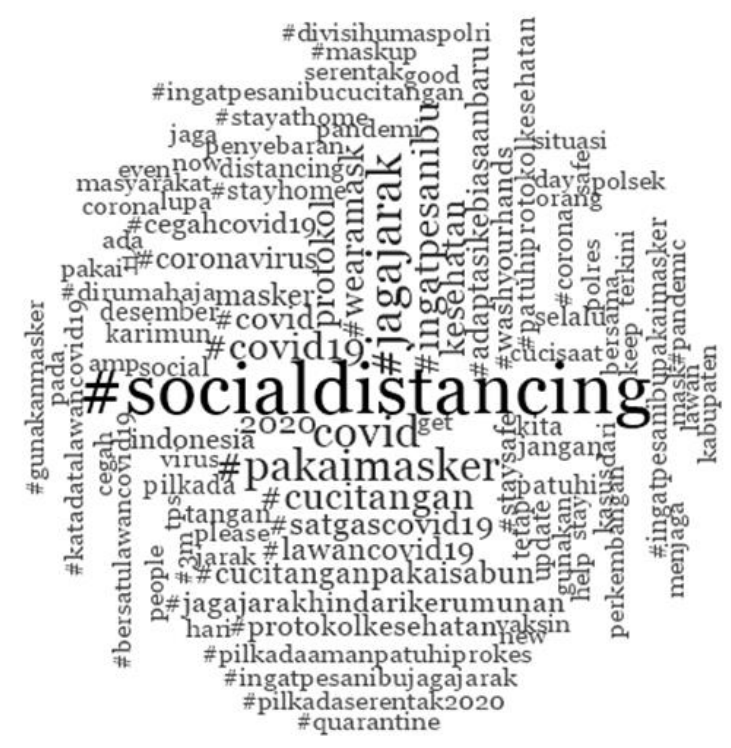

FIGURE 3. Word cloud of the hashtags

Based on world cloud analysis data using hashtags on social media Twitter related to health protocol campaigns. The most popular word that appears and is often discussed is \#socialdistancing. This shows that the Indonesian public, both the government and the public, is very concerned about campaigning for social distancing to break the chain of spreading Covid-19 in Indonesia. Public social media Twitter is also intensive and consistent use \#pakaimasker, \#cucitangan, \#jagajarak, \#Ingatpesanibu, \#patuhiprotokolkkes, \#adaptasikebiasaanbaru, \#jagajarakhindarikerumunan, \#covid19, community, \#pilkadapatuhiprokes several other words describe the seriousness of the Indonesian public, both government and society, in facing the Covid-19 pandemic.

Overall, about the health protocol campaign on social media Twitter, the Indonesian public discusses the prevention of Covid-19 transmission. This includes discussing health 
protocols, from washing hands, using masks to maintaining distance. It also concerns that the holding of regional head elections must apply health protocols so that the regional democratic party does not create a new cluster of the spread of Covid-19 in Indonesia. Among the topics of discussion, \#socialdistancing and Covid-19 were the most discussed by the Indonesian public. This is inseparable from the early emergence of Covid-19 in the world. Social distancing is an appeal that is often conveyed by authorities responsible to society.

Moreover, at the time of the initial entry of Covid-19 in Indonesia, social distancing was spread to the public to prevent Covid-19 transmission. Social distancing, also referred to as "physical distancing," helps maintain a safe space between yourself and others not from your family. Stay at least 6 feet (about two arms' length) from other people from your household in both indoor and outdoor spaces to practice social or physical distancing. Social distancing should be practiced in combination with other everyday preventive actions to reduce the spread of Covid-19, including wearing masks, avoiding touching your face with unwashed hands, and washing frequently (cdc.gov/coronavirus/2019).

But over time, the use of the term social distancing has shifted to physical distancing. This was also conveyed by the World Health Organization (WHO) that maintaining physical distance is very important amid a global pandemic that is still happening. This step does not mean that socially, a person should cut ties and communicate with loved ones or his family. WHO deliberately changed the term physical distancing because it wanted people to stay connected. The coronavirus is spread mainly through respiratory droplets, especially when an infected person coughs or sneezes. Therefore, maintaining a safe physical distance is recommended to reduce transmission(Mukaromah, 2020).

\section{CONCLUSION}

Based on the above discussion, it can be concluded that first, Twitter social media is one of the places to campaign for health protocols in the era of the Covid-19 pandemic, Second, the "physical distancing" health protocol campaign is dominant in \#SocialDistancing, "using a mask" is prevalent in \#jagajarak, and "handwashing" is often used in \#lawancovid19 and \#jagajarak. Third, several hashtags used in social media Twitter about health protocols are interconnected, but the most powerful are \#pakaimasker with \#jagajarak. Fourth, the most popular word about the health protocol campaign on Twitter is \#SocialDistancing.

The limitation of this research is that the data source only uses hashtags on social media Twitter. Therefore, recommendations for further research can use government social media accounts related to handling Covid-19 to get more complete data related to the health protocol campaign using social media.

\section{ACKNOWLEDGEMENT}

I want to thank the lecturer in the Global Governance and Comparative Government course, who has guided and provided suggestions for improving this research. Also, I thank Arissy Jorgy Sutan, who taught me to get the data in this research. 


\section{REFERENCES}

Adi Antoni, Arinil Hidayah, D. R. (2020). Penerapan Protokol Kesehatan Covid-19 pada Idul Fitri 1441 H di Perum Griya Nato Ujung Gurap. 2(2).

Allagui, I., \& Breslow, H. (2016). Social media for public relations: Lessons from four effective cases. Public Relations Review, 42(1), 20-30. https://doi.org/10.1016/j.pubrev.2015.12.001

Boulianne, S. (2015). Social media use and participation: a meta-analysis of current research. Information Communication and Society, 18(5), 524-538. https://doi.org/10.1080/1369118X.2015.1008542

Fitang Budhi Adhitia. (2020). Sejak Tiba di Indonesia Rizieq Memicu 5 Peristiwa Pengumpulan Massa. Retrieved November 1, 2020, from IDN TIMES Sulsel website: https://sulsel.idntimes.com/news/indonesia/fitang-adhitia/baru-sepekan-tiba-ini-5kegiatan-kontroversial-rizieq-di-indonesia-regional-sulsel/5

Garjito, D. (2020). Komunikasi Menkes Terawan Dikritik, 4 Pernyataan Soal Corona Jadi Sorotan. Retrieved from Suara.com website: https://www.suara.com/news/2020/03/04/101853/komunikasi-menkes-terawan-dikritik4-pernyataan-soal-corona-jadi-sorotan

Goodman, J., Wennerstrom, A., \& Springgate, B. F. (2011). Participatory and social media to engage youth: from the Obama campaign to public health practice. Ethnicity \& Disease, 2l( 30 1), S1.

Hassan, L., Nenadic, G., \& Tully, M. P. (2021). A Social Media Campaign (\#datasaveslives) to Promote the Benefits of Using Health Data for Research Purposes: Mixed Methods Analysis. J Med Internet Res, 23(2), e16348. https://doi.org/10.2196/16348

Irawan, D., Triana, N., Suwarni, L., \& ... (2020). Edukasi Protokol Kesehatan dan Strategi Pemasaran Online Melalui Program Kemitraan Masyarakat di Era Pandemi Covid-19. JMM (Jurnal Masyarakat ..., 4(4), 7-9. Retrieved from http://journal.ummat.ac.id/index.php/jmm/article/view/2636

Korda, H., \& Itani, Z. (2013). Harnessing social media for health promotion and behavior change. Health Promotion Practice, 14(1), 15-23.

Kostygina, G., Tran, H., Binns, S., Szczypka, G., Emery, S., Vallone, D., \& Hair, E. (2020). Boosting health campaign reach and engagement through use of social media influencers and memes. Social Media+ Society, 6(2), 2056305120912475.

Kumar, R., Kumar, S., \& Ilavarasan, P. V. (2017). Government portals , social media platforms and citizen engagement in India: Some insights. Procedia Computer Science, 122, 842-849. https://doi.org/10.1016/j.procs.2017.11.445

Kumar, V., \& Mirchandani, R. (2012). Increasing the ROI of Social Media Marketing. MIT Sloan Management Review, 54(1), 55-61.

Lim, M. (2017). Freedom to hate: social media, algorithmic enclaves, and the rise of tribal nationalism in Indonesia. Critical Asian Studies, 49(3), 411-427. https://doi.org/10.1080/14672715.2017.1341188

Mukaromah, V. F. (2020). WHO Gunakan Istilah Physical Distancing, Ini Bedanya dengan Social Distancing. Retrieved from Kompas.com website: https://www.kompas.com/tren/read/2020/04/01/061500965/who-gunakan-istilahphysical-distancing-ini-bedanya-dengan-social?page=all

Neiger, B. L., Thackeray, R., van Wagenen, S. A., Hanson, C. L., West, J. H., Barnes, M. D., \& Fagen, M. C. (2012). Use of social media in health promotion: Purposes, key performance indicators, and evaluation metrics. Health Promotion Practice, 13(2), 159164. https://doi.org/10.1177/1524839911433467 
Nisa, E. F. (2018). Social media and the birth of an Islamic social movement: ODOJ (One Day One Juz) in contemporary Indonesia. Indonesia and the Malay World, 46(134), 24 43. https://doi.org/10.1080/13639811.2017.1416758

Nugraheny, D. E. (2020a). 260 Bapaslon Langgar Protokol Kesehatan Saat Mendaftar Pilkada 2020. Retrieved November 1, 2020, from Kompas.com website: https://nasional.kompas.com/read/2020/09/08/11551181/260-bapaslon-langgar-protokolkesehatan-saat-mendaftar-pilkada-2020

Nugraheny, D. E. (2020b). KPU Sebut Ada 46 Bakal Calon Kepala Daerah Positif Covid-19. Retrieved November 1, 2020, from Kompas.com website: https://nasional.kompas.com/read/2020/09/08/12394071/update-kpu-sebut-ada-46bakal-calon-kepala-daerah-positif-covid-19

Paek, H. J., Hove, T., Jung, Y., \& Cole, R. T. (2013). Engagement across three social media platforms: An exploratory study of a cause-related PR campaign. Public Relations Review, 39(5), 526-533. https://doi.org/10.1016/j.pubrev.2013.09.013

Pedersen, E. A., Loft, L. H., Jacobsen, S. U., Søborg, B., \& Bigaard, J. (2020). Strategic health communication on social media: Insights from a Danish social media campaign to address HPV vaccination hesitancy. Vaccine, 38(31), 4909-4915. https://doi.org/https://doi.org/10.1016/j.vaccine.2020.05.061

Ristyawati, A. (2020). Efektifitas Kebijakan Pembatasan Sosial Berskala Besar Dalam Masa Pandemi Corona Virus 2019 oleh Pemerintah Sesuai Amanat UUD NRI Tahun 1945. Administrative Law and Governance Journal, 3(2), 240-249. https://doi.org/10.14710/alj.v3i2.240-249

Sari, D. N. A., Setyawan, A., Supriyadi, \& Purwitaningtyas, R. Y. (2020). Pengetahuan mahasiswa baru keperawatan tentang protokol COVID-19. 12(4), 711-718.

Siregar, S. N. (2020). Pelatihan Penerapan Protokol Kesehatan, Pembuatan Hand Sanitizer Alami Dan Ketahanan Pangan Keluarga Di Masa Pandemi Covid-19. Pusat Penelitian Politik, 4(5), 1018-1029. Retrieved from http://www.politik.lipi.go.id/kolom/kolom2/politik-nasional/1391-polri-di-masa-pandemi-covid-19-kompleksitas-masalahpenegakan-hukum-dan-pilihan-solusi

Sufiarina, \& Wahyuni, S. (2020). Force majeure dan notoir feiten atas kebijakan PSBB COVID-19. Jurnal Hukum Sasana, 6(1), 1-15. Retrieved from http://ejurnal.ubharajaya.ac.id/index.php/SASANA/article/view/209

Thompson, A., Hollis, S., Herman, K. C., Reinke, W. M., Hawley, K., \& Magee, S. (2020). Evaluation of a social media campaign on youth mental health stigma and help-seeking. School Psychology Review, 50(1), 36-41.

Tuti Meihartati, Aries Abiyoga, Dodi Saputra, I. S. (2020). Pentingnya Protokol Kesehatan Keluar Masuk Rumah Saat Pandemi Covid-19 Di Lingkungan Masyarakat RT 30 Kelurahan Air Hitam, Samarinda, Kalimantan Timur. Jurnal Abdimas Medika, 1(2), 116.

Untari, P. H. (2020). Apa Itu PSBB Transisi? Retrieved November 1, 2020, from Okezone.com website: https://www.okezone.com/tren/read/2020/06/06/620/2225424/apa-itu-psbb-transisi

Valenzuela, S. (2013). Unpacking the Use of Social Media for Protest Behavior: The Roles of Information, Opinion Expression, and Activism. American Behavioral Scientist, 57(7), 920-942. https://doi.org/10.1177/0002764213479375

Vergeer, M., \& Hermans, L. (2013). Campaigning on Twitter: Microblogging and Online Social Networking as Campaign Tools in the 2010 General Elections in the Netherlands. Journal of Computer-Mediated Communication, 18(4), 399-419. https://doi.org/10.1111/jcc4.12023 
Yoo, S.-W., Kim, J., \& Lee, Y. (2018). The effect of health beliefs, media perceptions, and communicative behaviors on health behavioral intention: An integrated health campaign model on social media. Health Communication, 33(1), 32-40.

\section{ABOUT THE AUTHOR}

Dimas Subekti is a student in Master of Government Affairs and Administration, Jusuf Kalla School of Government, Universitas Muhammadiyah Yogyakarta, Yogyakarta, Indonesia since September 2020.

Dr. Suranto, M.Pol. is a lecturer in Master of Government Affairs and Administration, Jusuf Kalla School of Government, Universitas Muhammadiyah Yogyakarta, Yogyakarta, Indonesia. 